\title{
Crustal Structure of the Salton Trough: Incorporation of Receiver Function, Gravity and Magnetic Data
}

\author{
Musa Hussein, Aaron Velasco, Laura Serpa \\ Department of Geological Sciences, University of Texas at El Paso, El Paso, USA \\ E-mail: \{mjhussein, aavelasco, lfserpa\}@utep.edu \\ Received June 1, 2011; revised July 26, 2011; accepted September 17, 2011
}

\begin{abstract}
The Salton Trough of southwestern California is inferred to be an incipient ocean basin, and is a polyphase basin with significant extension in addition to dextral shear. To further explore the origin and evolution of this basin, we have incorporated receiver function, gravity, and aeromagnetic data to construct new subsurface crustal scale models. Receiver function analysis suggests the Moho is $20 \mathrm{~km}$ deep to the southwest of the Salton Sea and deepens to $32 \mathrm{~km}$ in the region east of the Salton Trough and dome in shape. Crustal modeling shows that the density of the lower crust is $2950 \mathrm{~kg} / \mathrm{m}^{3}$, which is an indication for gabbroic composition, while the density of the upper crust varies from $2500 \mathrm{~kg} / \mathrm{m}^{3}$ to $2600 \mathrm{~kg} / \mathrm{m}^{3}$ and the depth of sedimentary and meta-sedimentary rocks appears to be $8-10 \mathrm{~km}$. Most magnetic anomalies show shallow relief and are low amplitude with some exceptions in the marginal areas, suggesting the absence of shallow buried mafic intrusions and deep basement. Our models show a magmatic body to the southwest of the Salton Sea at depth of about $18 \mathrm{~km}$ and extend in SW-NE direction for about $90 \mathrm{~km}$, We expect this magmatic body (mixture of lower crust and upper mantle material) is responsible for crustal thinning, stretching and rifting, according to the crustal models this body doesn't exist in the north region of Salton Trough, thus, no further propagate of the rift is expected in the north.
\end{abstract}

Keywords: Data Incorporation, Crustal Models, Magmatic Body, Salton Trough

\section{Introduction}

The Salton Trough (Figure 1), a large polyphase basin, lies in the transition zone between the East Pacific Rise (divergent plate boundary) and the right-lateral San Andreas Fault (transform boundary). The Salton Trough, which is characterized by young volcanism and the presence of several pull-apart basins both north and south of the US-Mexico border, has high heat flow [1] and has been inferred to be in the early stage of evolution from continental to oceanic crust. The Salton Trough serves as an ideal region to study divergent plate boundary evolution and to determine the role of magmatism and sedimentation on continental extension.

Many questions remain about how rifting will propagate to the north, and the exact processes that drive basin evolution and rifting. For example, is the Salton Trough an example of completely new crustal generation (magmatic addition from below, and sedimentary addition from above) as suggested by [2]? Is there a magmatic body that underlies the central basin of Salton Trough, and what is the geometry of this body? Is the lower crust of the Salton Trough oceanic (gabbroic) in composition or mixture of oceanic and continental crust?

To answer these questions, we incorporated receiver function, gravity, and aeromagnetic data to develop 2.5D models for the Salton Trough area. In particular, we use data from the southern California broadband seismic network and data collected by the EarthScope USArray seismic deployment for receiver function analysis. We also mine data from existing gravity databases from the University of Texas at El Paso (UTEP)-Pan American Center of Earth and Environmental Studies (PACES) (http://www.research.utep.edu/paces) that is currently hosted at the CYBER-ShARE Center of Excellence at UTEP. Aeromagnetic data were obtained from the U.S. Geological Survey [3]. We then constrain our models by using previously defined seismic models and their interpretation. By utilizing this breadth of data, we can derive information about compositional variation, underplating, 


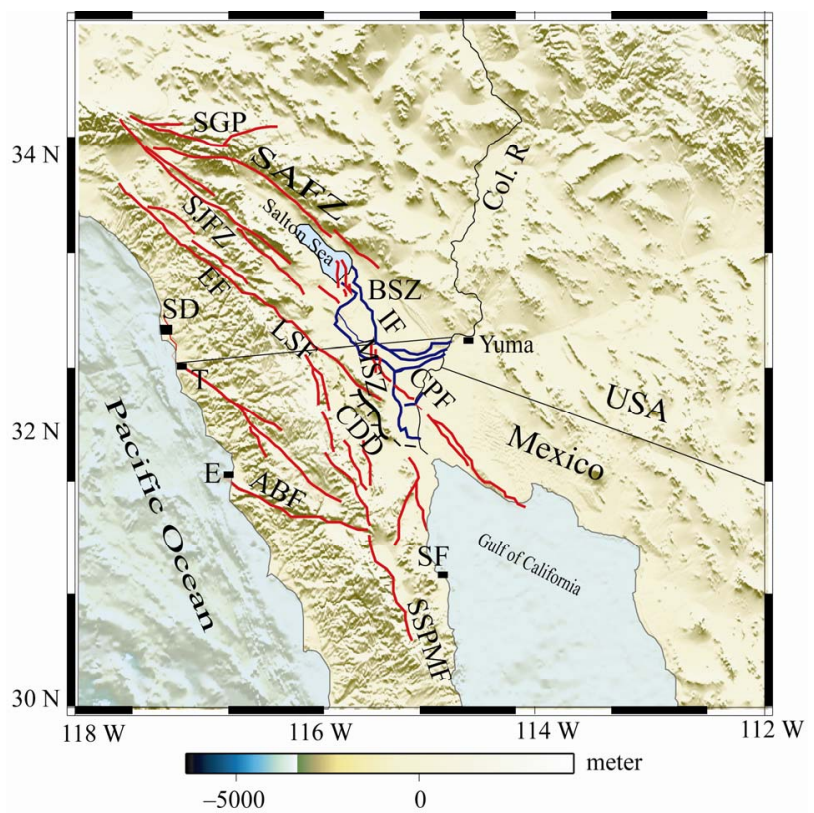

Figure 1. Location map of the Salton Trough and surrounding areas. Faults of the northern Gulf of California and Salton Trough region. ABF-Agua Blanca fault; BSZ-Brawley seismic zone; CDD-Canada David detachment; CPFCerro Prieto fault; E-Ensenada; EF-Elsinore fault; IF-Imperial fault; LSF-Laguna Salada fault; MSZ-Mexicali seismic zone; SAFZ-San Andreas fault zone; SD-San Diego; SGP-San Gorgonio Pass; SF-San Felipe; SJFZ-San Jacinto fault zone; SSPMF-Sierra San Pedro Martir fault; T-Tijuana. After [42].

crust type (e.g. oceanic vs. continental), depth to the basement, and depth to the Moho, which we can use to infer the evolution of the Salton Trough.

\section{Tectonic Setting}

The Salton Trough results from northward progression of the enlarging Gulf of California [1,4-8]. The initial opening of the Gulf of California occurred about 12 - $10 \mathrm{Ma}$, shortly after subduction ceased along the continental margin of Mexico [8,9]. Rifting in the Gulf of California began as a response to major plate-margin reorganization and roughly the same amount of strain has accumulated across the various basins north to south [10].

Opening of the Gulf of California is often attributed to two sequential extensional events: middle to late Miocene "protogulf" extension [5,9,11,12], and the Pliocene development of the Pacific-North America plate boundary from about $5.5 \mathrm{Ma}$ to the present [4,13]. Several causes have been proposed for the late Miocene circumgulf extension [9]. Reference [11] suggested that it was back arc extension, but more precise constraints on the cessation of subduction west of Baja California by [8] show that it was not contemporaneous with active subduction. The geographic continuity and similarity in extension direction, of the Gulf extensional Province and the southern Basin and Range extensional province (in Arizona and Sonora) invited suggestions that this entire Miocene extensional belt resulted from the same process as Basin and Range extension [13-15].

The Salton Trough contains about 8 - $10 \mathrm{~km}$ of sediment deposited as alluvial debris, thin marine beds, and deposits from the ancestral Colorado River [7]. The present day Salton Trough differs from analogous structures to the south in the Gulf of California primarily because of large amounts of sediment deposited through the growth of the Colorado River delta during the past 5 m.y. [16]. This sedimentation may play a strong role in reducing the apparent structural relief in the Salton Trough [16]. The rapid flux of sediment to these basins exerts a strong influence on deformation style, crustal rheology, syn-rift magmatism, and rift architecture [17-19], though many aspects of this control remain poorly understood. The Colorado River has delivered a large volume of sediment to these basins over the past 5 - 6 m.y., supplying felsic material that is quickly buried and metamorphosed to form a new generation of crust transferred from the craton interior [20].

\section{Data}

\subsection{Receiver Functions}

A receiver function is the seismic response of the earth beneath a seismic station to an incoming $P$-wave. In particular, a receiver function maps $P$-to- $S$ converted energy that occurs from impedance contrasts (i.e., layers of different velocity and density) in the earth. First-order information about the crustal structure can be derived from the radial receiver function, which is dominated by $P$-to$S$ converted energy from a series of velocity discontinuities in the crust and upper mantle [21]. Thus, receiver functions can provide very good point measurements of crustal thickness under a broadband station. Because of the large velocity contrast at the crust and mantle boundary, the Moho P-to-S conversion (Ps) is often the largest signal following the direct $P$ [22]. Receiver functions can be used to determine crustal thickness and $V_{p} / V_{s}$ ratios, and to determine the lateral variation of the Moho depth [22]. For example, in regions of lithospheric extension, one would expect to find a thin crust and therefore a shallow Moho.

We employed the receiver function technique using the iterative deconvolution method of [23] and the stacking approach described in [22]. In receiver function estimation, the foundation of the iterative deconvolution 
approach is least squares minimization of the difference between the observed horizontal component seismogram and predicted signal generated by convolution of an iterative updated spike train with the vertical component seismogram [23]. The iterative time-domain approach has several advantages, such as the ability to estimate the percent fit and the long period stability by a priori constructing the deconvolution as a sum of Gaussian pulses [23]. We computed receiver functions using the iterative time deconvolution with Gaussian width (Ga) factors of $2.5,1.75$, and 1 which is equivalent to applying low pass filters with cutoff frequencies of $1.2,0.9$, and $0.5 \mathrm{~Hz}$, respectively.

We collected data from 27 broadband seismograph stations (listed in Table 1 and shown in Figure 2), that recorded data from 2000 to 2009 and cover the Salton Trough and surrounding areas. Specifically, we collected broadband seismic waveform data for teleseismic earthquakes with $M>5.5$. These data were downloaded directly from the Incorporated Research Institutes for
Seismology (IRIS), Data Management Center (DMC), using the Standing Order of Data (SOD), which allowed for automated rotation of the horizontal components to radial and transverse directions. From the waveform data, we computed the radial and transverse receiver functions using iterative deconvolution, keeping data with an $80 \%$ or greater fit.

We also manually inspected each radial receiver function to ensure quality. We then stacked the radial receiver functions using the approach of [22].

The time separation between $P$ s and $P$ can be used to estimate crustal thickness $(H)$, given the average crustal velocity:

$$
H=\frac{t_{p s}}{\sqrt{\frac{1}{V_{s}^{2}}-p^{2}}-\sqrt{\frac{1}{V_{p}^{2}}-p^{2}}}
$$

where $p$ is the ray parameter of the incident wave. One problem is the trade-off between the thickness and

Table 1. Stations codes, coordinates, estimated $V_{p} / V_{s}$, crustal thickness and number of receiver functions used in this study.

\begin{tabular}{|c|c|c|c|c|c|c|}
\hline No. & Station Code & Longitudes & Latitudes & Est. $V_{p} / V_{s}$ & Est. Crustal Thickness & No. of RF \\
\hline 1 & Cl-ADO & -117.43 & 34.55 & $1.74 \pm 0.01$ & $36.49 \pm 0.32$ & 168 \\
\hline 2 & Cl-BBR & -116.92 & 34.26 & $1.95 \pm 0.10$ & $29.00 \pm 0.34$ & 205 \\
\hline 3 & Cl-BC3 & -115.45 & 33.66 & $1.80 \pm 0.11$ & $25.50 \pm 0.32$ & 216 \\
\hline 4 & Cl-BEL & -116.00 & 34.00 & $1.76 \pm 0.12$ & $28.59 \pm 0.12$ & 245 \\
\hline 5 & Cl-BFS & -117.66 & 34.24 & $1.81 \pm 0.10$ & $31.00 \pm 0.33$ & 202 \\
\hline 6 & Cl-DAN & -115.38 & 34.63 & $1.69 \pm 0.08$ & $28.03 \pm 0.28$ & 411 \\
\hline 7 & Cl-DVT & -116.10 & 32.66 & $2.07 \pm 0.11$ & $20.50 \pm 0.58$ & 18 \\
\hline 8 & Cl-GLA & -114.83 & 33.05 & $1.67 \pm 0.12$ & $27.00 \pm 0.38$ & 493 \\
\hline 9 & Cl-HEC & -116.34 & 34.83 & $1.79 \pm 0.09$ & $28.44 \pm 0.27$ & 260 \\
\hline 10 & Cl-IRM & -115.15 & 34.16 & $1.80 \pm 0.10$ & $27.00 \pm 0.33$ & 239 \\
\hline 11 & Cl-NEE & -14.60 & 34.82 & $1.87 \pm 0.11$ & $25.96 \pm 0.38$ & 27 \\
\hline 12 & Cl-PDM & -114.14 & 34.30 & $1.73 \pm 0.10$ & $27.96 \pm 0.32$ & 230 \\
\hline 13 & Cl-RRX & -117.00 & 34.86 & $1.88 \pm 0.10$ & $30.49 \pm 0.33$ & 253 \\
\hline 14 & Cl-SWS & -115.80 & 32.94 & $1.61 \pm 0.09$ & $27.96 \pm 0.27$ & 166 \\
\hline 15 & Cl-GMR & -115.66 & 34.78 & $1.77 \pm 0.11$ & $26.57 \pm 0.42$ & 147 \\
\hline 16 & Cl-MUR & -117.20 & 33.60 & $1.77 \pm 0.09$ & $31.15 \pm 0.30$ & 171 \\
\hline 17 & TA-109C & -117.11 & 32.89 & $1.64 \pm 0.11$ & $38.56 \pm 0.34$ & 30 \\
\hline 18 & TA-112A & -114.58 & 32.54 & $1.79 \pm 0.08$ & $25.06 \pm 0.46$ & 29 \\
\hline 19 & TA-Y12C & -114.52 & 33.75 & $1.63 \pm 0.09$ & $33.49 \pm 0.25$ & 83 \\
\hline 20 & TA-W13A & -113.90 & 35.10 & $1.77 \pm 0.09$ & $28.91 \pm 0.30$ & 54 \\
\hline 21 & TA-X13A & -113.80 & 34.60 & $1.76 \pm 0.09$ & $26.98 \pm 0.35$ & 65 \\
\hline 22 & TA-Y13A & -113.83 & 33.81 & $1.72 \pm 0.12$ & $30.4 \pm 0.35$ & 73 \\
\hline 23 & NR-NE70 & -115.26 & 32.42 & $2.35 \pm 0.06$ & $25.50 \pm 0.21$ & 8 \\
\hline 24 & NR-NE71 & -115.91 & 31.69 & $1.83 \pm 0.10$ & $32.50 \pm 0.38$ & 136 \\
\hline 25 & NR-NE72 & -116.06 & 30.85 & $1.85 \pm 0.10$ & $32.10 \pm 0.33$ & 34 \\
\hline 26 & AZ-MONP & -116.42 & 32.89 & $1.78 \pm 0.09$ & $30.49 \pm 0.26$ & 249 \\
\hline 27 & AZ-PFO & -116.46 & 33.61 & $1.81 \pm 0.11$ & $27.05 \pm 0.38$ & 419 \\
\hline
\end{tabular}




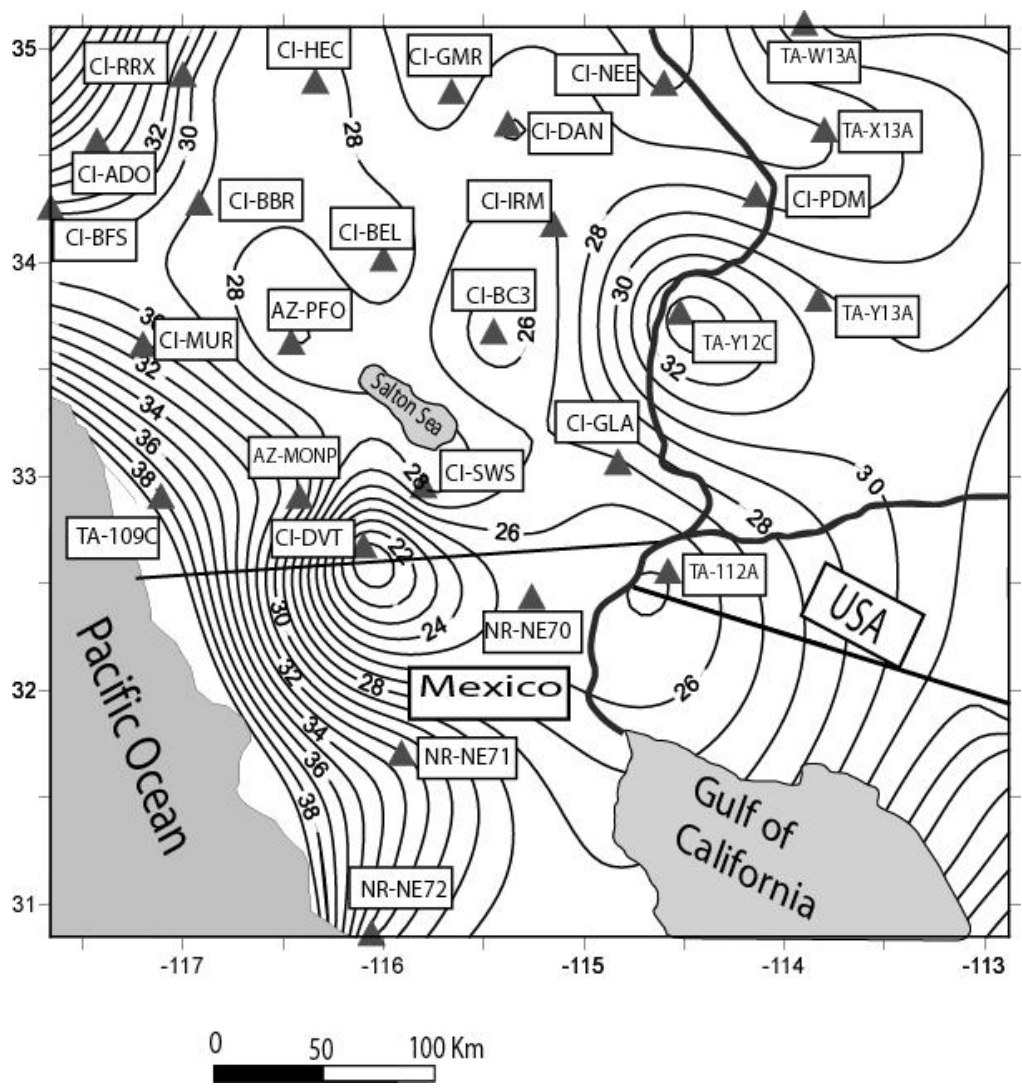

Figure 2. Contour map of the Moho depth based on receiver function data. Data were collected from 27 stations (shown as triangles). Stations codes are shown inside small squares beside each station.

crustal velocities, since $t_{P s}$ represents the differential travel time of $S$ with respect to $P$ in the crust. The dependence of $(H)$ on $V_{p}$ is not as strong as on $V_{s}$ or more precisely on the $V_{p} / V_{s}$ ratio $(K)$, which means the uncertainty of $(H)$ is $<0.5 \mathrm{~km}$ for a $0.1 \mathrm{~km} / \mathrm{s}$ uncertainty in $V_{p}$; while a 0.1 change in $(K)$ can lead to about $4 \mathrm{~km}$ change in the crustal thickness [22]. This ambiguity can be reduced by using a later phase, which provides additional constraints so that both $(K)$ and $(H)$ can be estimated [2426].

Figure 3 shows $H-K$ stacks for selected stations (BBR, BC3, GLA, SWS) within the study area; the results for the stacks give good estimates of the crustal thickness and the $V_{p} / V_{s}$ ratio. We find that our stacking results differ slightly (difference ranges from 0 to $4 \mathrm{~km}$ ) for several stations than those reported by the EarthScope Automated Receiver Survey (EARS), which are likely due to different selection criteria for data to be included in the stacks, differing amounts of data, and different quality control. Using the results from receiver functions, we contour the Moho depth (Figure 2) using a minimumcurvature algorithm to interpolate values to a rectangular grid. The Moho has a dome shape, suggested to be primarily the product of magmatic activity in the lower crust and upper mantle, with the Moho depth to the southwest of Salton Sea at $20 \mathrm{~km}$ and deepening to 32 $\mathrm{km}$ to the east. The average $V_{p} / V_{s}$ ratio is 1.80 ; it increases to the south to (2.07 to 2.35) and decreases to the east and southeast to $(1.61$ - 1.67). The major factor producing high $V_{p} / V_{s}$ is the plagioclase-rich mafic composition of the lower crust [27]. Reference [28] concluded that low velocity associated with high $V_{p} / V_{s}$ zones in the lower crust and the uppermost mantle is caused by melt inclusions.

\subsection{Gravity and Magnetic Data}

We obtained gravity data from UTEP-PACES (http:// www.research.utep.edu/paces) that is currently hosted at the CYBER-ShARE Center of Excellence at UTEP. The gravity data available were merged from a variety of surveys and cover the U.S. and the border region. Average errors for this data set range from 0.05 to $2 \mathrm{mGal}$ [Raed Al-Douri, personal communication, 2008]. Terrain corrections were calculated by [29] using a digital elevation model and a technique based on the approach of [30]. Bouguer gravity corrections were made using 2670 $\mathrm{kg} / \mathrm{m}^{3}$ as the reduction density. We used 40,784 Bouguer 

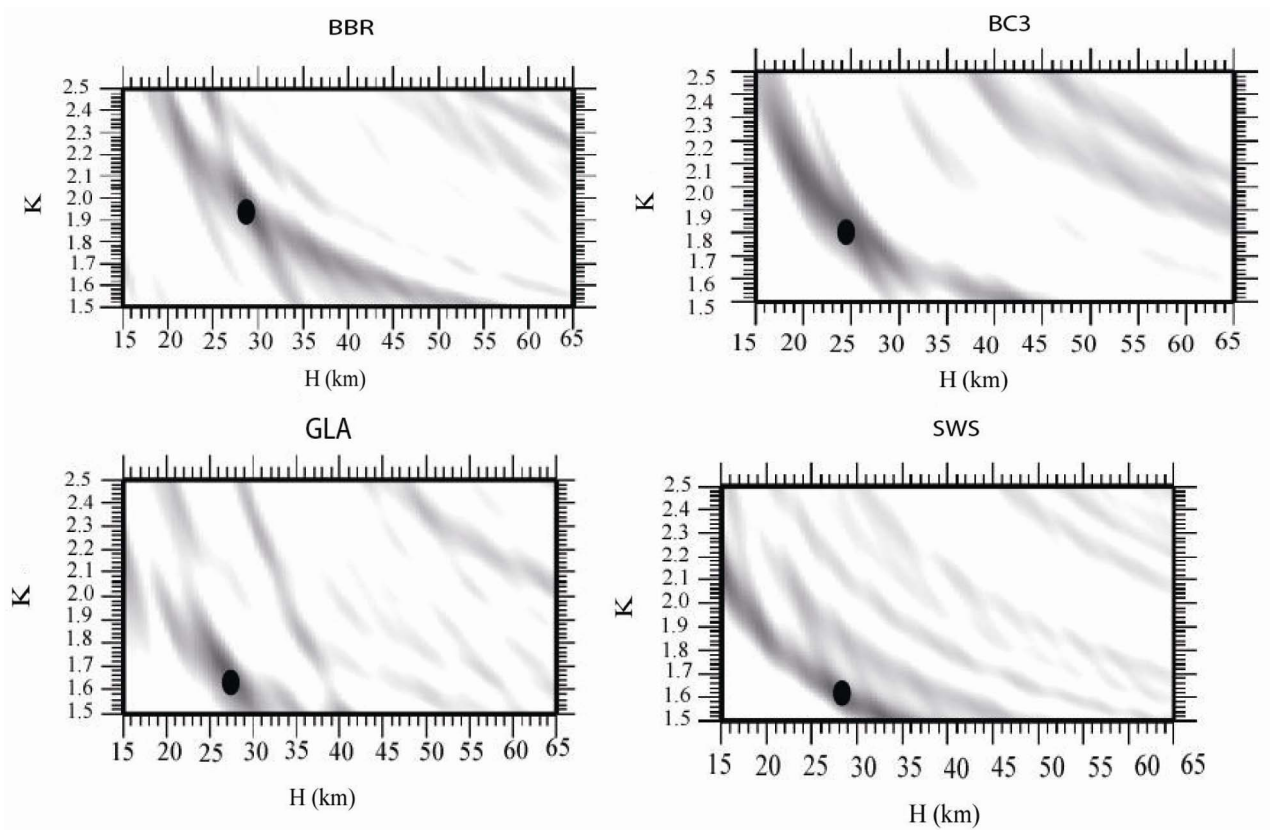

Figure 3. H-K stacks for stations BBR, BC3, GLA, and SWS. The black dots represent the maximum value of the stacks. Depth to the Moho at station BBR is $29 \mathrm{~km}$, depth to the Moho at station BC3 is $24 \mathrm{~km}$, depth to the Moho at station GLA is $27 \mathrm{~km}$, and depth to the Moho at station SWS is $29 \mathrm{~km}$.

gravity points to create the Bouguer gravity anomaly map (Figure 4). Aeromagnetic data were obtained from the USGS [3], California Geological Survey (CGS), and the Mexican Survey were combined to produce a (1) km grid of North America [3]. For this study we filtered the grid to produce a reduced-to-pole magnetic anomaly map (Figure 5). The process of reduction to the pole [31] is used to transform the observed magnetic anomaly so that it represents the anomaly that would result from an induced magnetization and ambient field directed vertically downward (i.e., as if at the north magnetic pole) [32]. Reduction to the pole shifts the anomaly to a position directly over its source, making it easier to interpret the location of magnetic bodies [32]. We use a total of 112,436 aeromagnetic measurement points to create the magnetic anomaly map (Figure 5).

\section{Model Development}

We begin model development by examining the unfiltered Bouguer gravity, magnetic anomaly maps, receiver function analysis and developing 2.5-D crustal models using the results from seismic studies to constrain our interpretation.

\subsection{Bouguer Gravity Anomaly and Magnetic Anomaly Maps}

The Bouguer gravity map indicates that the most impor- tant gravity anomalies trend in the NW and NE directions (Figure 4). Large amplitude gravity anomalies ( -40 to $-20 \mathrm{mGal}$ ) are combination of higher density crystalline rocks and thin crust.

Low amplitude gravity and magnetic anomalies are observed in the coastal region of the study area (labeled number 1 in Figures 4 and 5), and coincide with the Peninsular Ranges.

High amplitude gravity anomalies coincide with shallow Moho $(20 \mathrm{~km})$ to the southwest of Salton Sea (labeled number 2 Figure 4). The same area is underlie by underplated material (mix of lower crust and upper mantle material with proposed density of $3100 \mathrm{~kg} / \mathrm{m}^{3}$ ), that causes uplifting, crustal stretching, and rifting.

Metamorphic core complex (MCC) (Buckskin-Rawhide MCC) (labeled number 3 in Figure 4) is located in the northeast region ( -90 to $-70 \mathrm{mGal}$ ). This core complex lacks a strong Bouguer gravity anomaly. Thus regardless of its source, the material that maintains crustal thickness beneath the core complex must have approximately the same density as average crust [16]. The crust under the core complex is $(\sim 28 \mathrm{~km})$ and is thicker than the surrounding areas.

Gila River anomaly (labeled number 4 in Figure 4) large amplitude gravity anomaly along Gila River extends for about $200 \mathrm{~km}$ within the Salton Trough and southwest Arizona in east west direction. This large amplitude gravity anomaly is a response to the Farallon plate remnant beneath the Pelona Orocopia schist ex- 


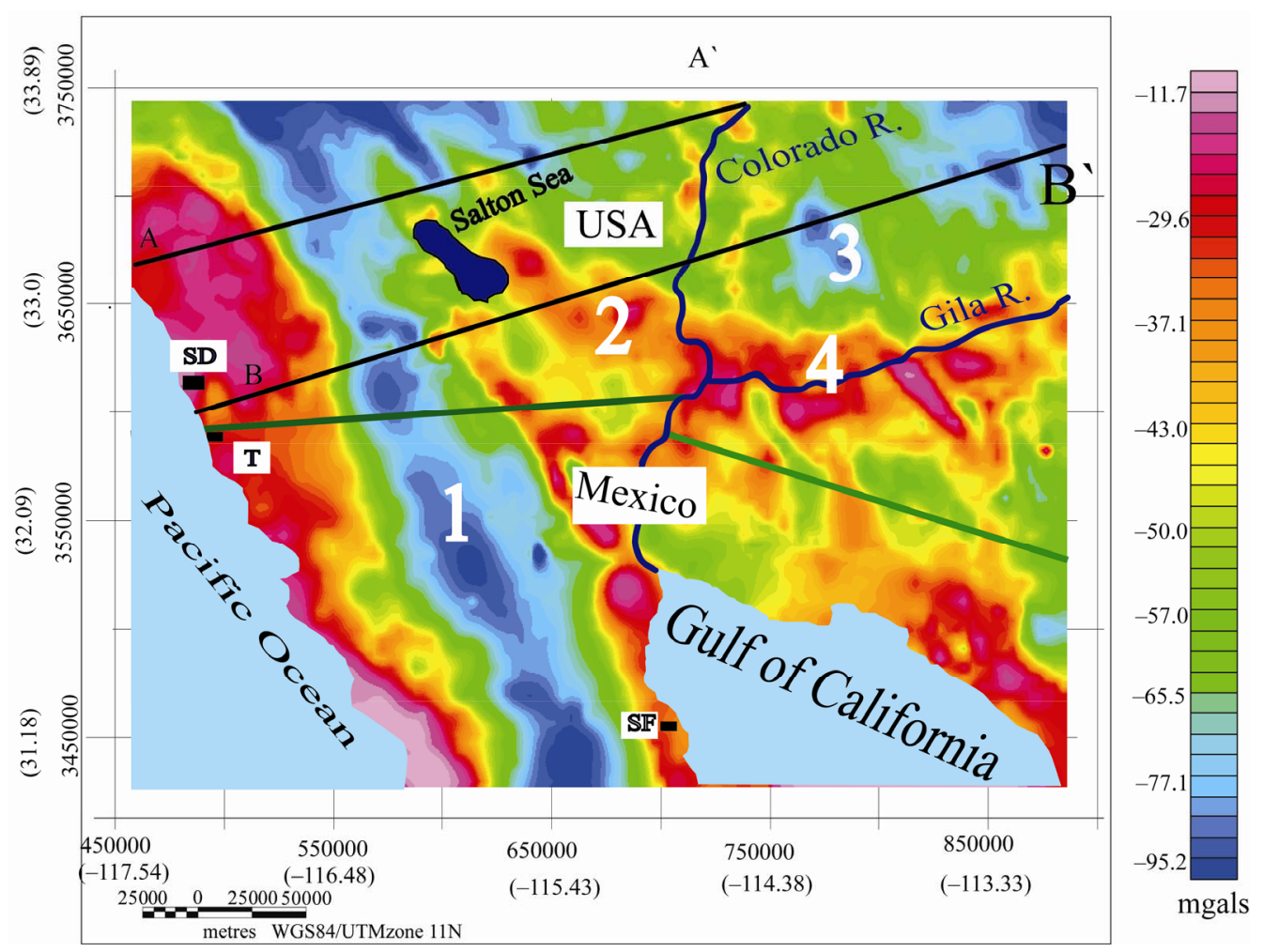

Figure 4. Bouguer gravity anomaly map of the Salton Trough area. Numbers refer to anomalies discussed in the text. Solid lines A-A', B-B` show the locations of the crustal profiles. Map was projected using UTM projection geographic coordinates are also shown on the figure.

posed north of Yuma (Figure 1). The Farallon plate scarped off the lower crust and upper mantle before underplating the schist and now forms the lower continental crust, and this dense plate causing the large gravity anomaly (Jon Spencer, personal communication, 2010).

Most magnetic anomalies trend in NW direction (Figure 5). Large amplitude magnetic anomaly coincides with Tertiary and Quaternary volcanic rocks to the east of Colorado River where metamorphosed Precambrian and Paleozoic rocks are exposed in that area. Different rock types, such as mafic plutons exposed in the western Peninsular Ranges and along the west edge of the southern Sierra Nevada, have different magnetic signatures due to differences in magnetic susceptibility. Anomaly labeled as number 1 (low amplitude magnetic) is a response to exposed granitic rocks along the Peninsular Ranges. Anomaly 2 (high amplitude magnetic) is likely a response to tabular body or shallow basement, while anomaly 3 (high amplitude magnetic) coincide with Little Sam Bernardino Mountains.

\subsection{Crustal Models}

We developed two 2.5-D crustal models (Figures 6 and 7) that were constructed using the approach of [33], fur- ther revised by [34,35]. Gravity and magnetic values were extracted from the grid by interpolation at a $3 \mathrm{~km}$ interval for both models A-A ' and B-B (Figures 6 and 7). These values were then input as observed data into the 2.5-D forward modeling program. The locations of the profiles were chosen to illustrate the general crustal structure of the region, not necessarily to explain the surface geology. For all models, near surface bodies were constructed using the geologic maps of California [36], and Arizona [37]. In general, gravity modeling produces non-unique results; thus, it is helpful to start with other information such as known geologic relationships, crustal thickness information from receiver function analysis, and previous crustal studies.

As starting point in modeling, the depth to the Moho was determined from receiver function, information and densities for the upper and lower crust and upper mantle were inferred from previous studies $[2,16,38]$. Densities for the upper crust vary from $2500 \mathrm{Kg} / \mathrm{m}^{3}$ to $2600 \mathrm{~kg} / \mathrm{m}^{3}$, we expect higher density in the Peninsular Ranges and lower density in other areas, and in the lower crust densities vary from $2750 \mathrm{~kg} / \mathrm{m}^{3}$ to $2950 \mathrm{~kg} / \mathrm{m}^{3}$. Lower crust density for all models reflects gabbroic composition of the lower crust or oceanic crust which indicates a late stage of rifting. Magnetic susceptibilities were estimated 

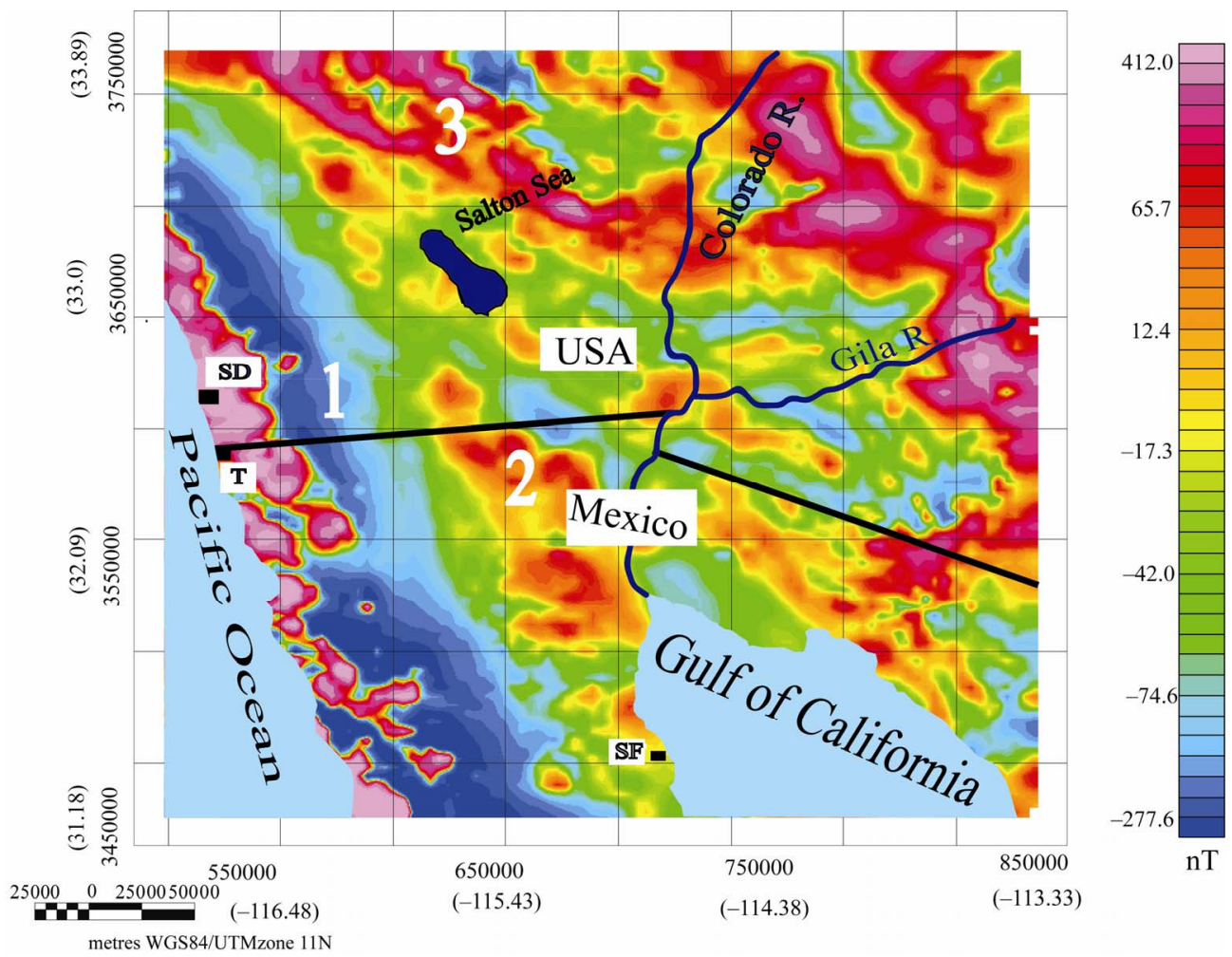

Figure 5. Magnetic anomaly map of the Salton Trough. Numbers indicate anomalies discussed in text. Map was projected using UTM projection geographic coordinates are also shown on the figure.

\section{A (Southwest)}

A` (Northeast)
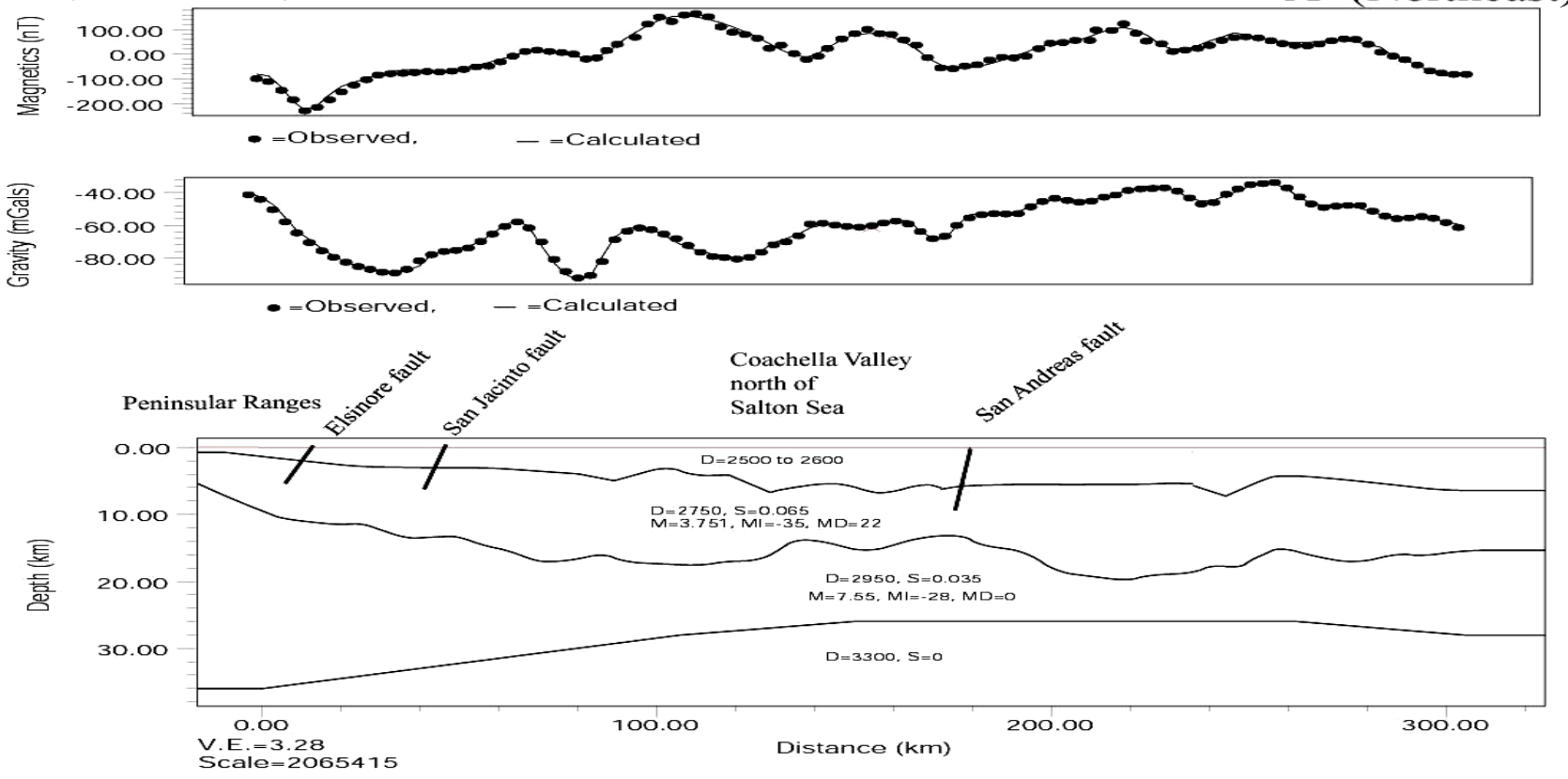

Figure 6. Interpretative model for gravity and aeromagnetic data profile A-A` (Northern region of Salton Trough). (See Figure 4 for location of profile). Depth to the Moho ranges from $36 \mathrm{~km}$ at the starting point (A) of the model increasing to 28 $\mathbf{k m}$ at the central and increasing to $30 \mathrm{~km}$ at the end point (A $\left.{ }^{`}\right)$ of the model. Bold lines are major crustal faults. [D = Density $\left(\mathrm{kg} / \mathrm{m}^{3}, \mathrm{~S}=\right.$ Susceptibility (dimensionless), $\mathrm{M}=$ Magnetization $(\mathrm{A} / \mathrm{m}), \mathrm{MI}=$ Magnetic inclination $($ degree$), \mathrm{MD}=\mathrm{Magnetic}$ declination (degree)]. 


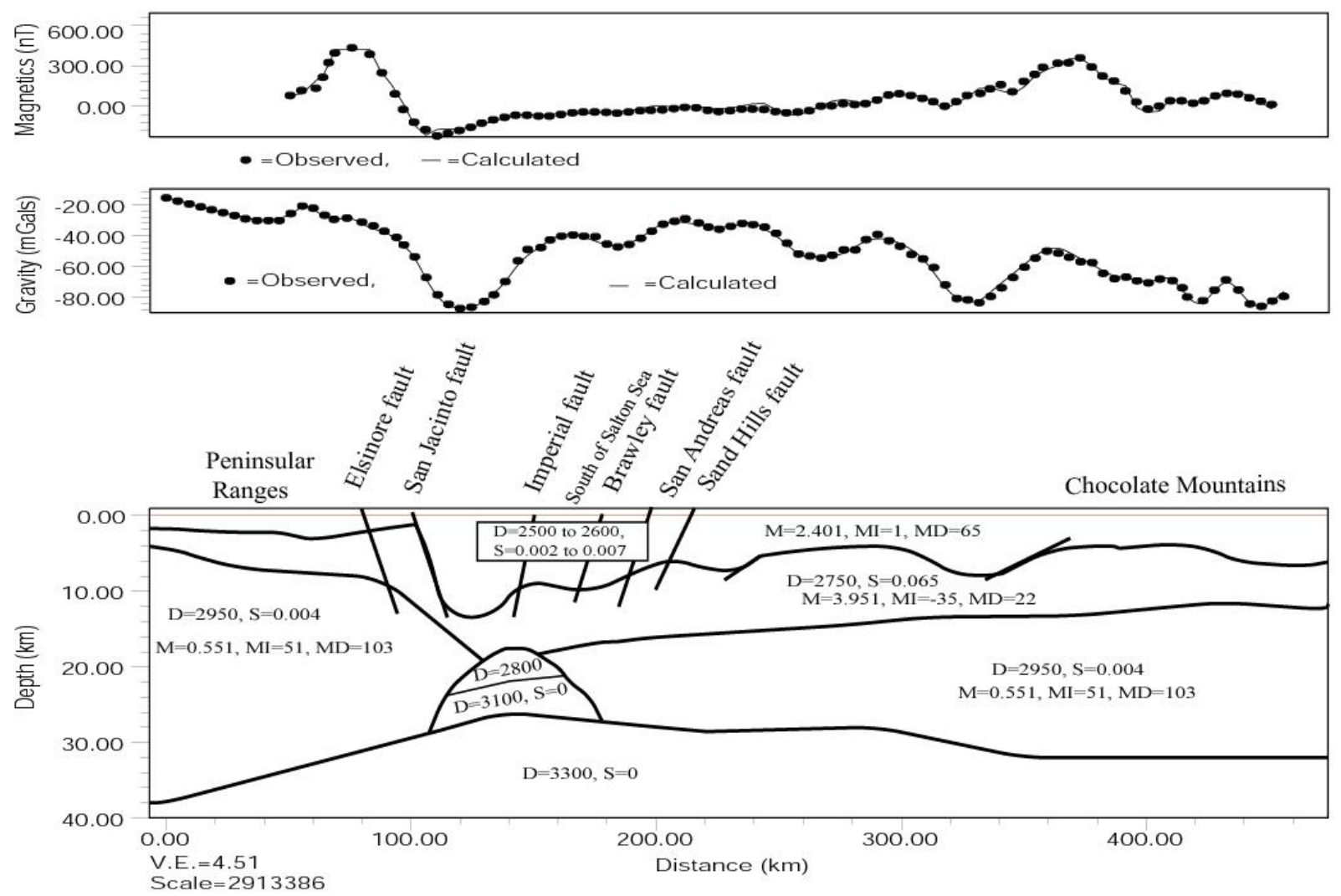

Figure 7: Interpretative model for gravity and aeromagnetic data profile B-B`(Central region of Salton Trough). (See Figure 4 for location of profile). This model is about $\sim 450 \mathrm{~km}$ long, covers the central part of the study area. The depth to the Moho, according to the receiver functions, varies from $25 \mathrm{~km}$ at the central point of the model south of Salton Sea, and deepens to 28 $\mathbf{k m}$ under the metamorphic core complex and increases to $32 \mathrm{~km}$ at the end point $\left(B^{\prime}\right)$ of the profile. [D $=$ Density $\left(\mathrm{kg} / \mathrm{m}^{3}, \mathrm{~S}=\right.$ Susceptibility (dimensionless), $\mathrm{M}=$ Magnetization (A/m), MI = Magnetic inclination (degree), MD = Magnetic declination (degree)].

from [39]. Depth, density, and magnetic susceptibility were varied within $25 \%$ of initial values to determine a final model that best fit matched receiver function, gravity and magnetic data. The final models have a misfit of approximately $2.0 \mathrm{mGal}$ for gravity, and $6-8 \mathrm{nT}$ for magnetic data.

Model A-A`(Figure 6) is about $300 \mathrm{~km}$ long and covers the northern part of the Salton Trough. Depth to the Moho according to receiver function results ranges from $36 \mathrm{~km}$ at the starting point (A) of the model decreasing to $26 \mathrm{~km}$ at the central and increasing to $28 \mathrm{~km}$ at the end point (A') of the model.

Model B-B` (Figure 7) is about $420 \mathrm{~km} \mathrm{long,} \mathrm{and}$ covers the central part of the study area to the south of the Salton Sea. The depth to the Moho, according to the receiver function, varies from $38 \mathrm{~km}$ at the starting point B decreases to $26 \mathrm{~km}$ to the southwest of the Salton Sea, and increases to $32 \mathrm{~km}$ at the end point (B`) of the model. Magmatic underplating occurs at a depth of ( 18 $\mathrm{km})$ to the southwest of Salton Sea. Magmatic underplating caused the uplifting, melting and recrystallization of the lower crustal rocks and produced extension and basin sedimentation in the upper crust [16].

Our models show a steeply dipping Moho beneath the Peninsular Ranges, suggest that compensation is through lateral variation in crustal and or upper mantle density rather than through an Airy root [40]. Magmatic underplating occurs beneath the central regions of the Salton Trough, but not in the northern and western regions; thus, the rift is not expect to propagating to the north, or west.

\section{Discussion}

The Moho in our models is dome shaped, with a minimum of $20 \mathrm{~km}$ in depth to the southwest of Salton Sea, increasing to $32 \mathrm{~km}$ and $27 \mathrm{~km}$ on its eastern and northeastern flanks, respectively (Figure 2). This shape is suggested to be primarily the product of magmatic activ- 
ity in the lower crust and upper mantle. According to our models the lower crust density ranges from $2750 \mathrm{~kg} / \mathrm{m}^{3}$ to $2950 \mathrm{~kg} / \mathrm{m}^{3}$. These values represent gabbros, not a mixture of oceanic and continental crust, while upper crust densities range from $2500 \mathrm{~kg} / \mathrm{m}^{3}$ to $2600 \mathrm{~kg} / \mathrm{m}^{3}$. The large density variation between the upper and lower crust suggests that the Salton Trough has formed almost entirely from magmatism in the lower crust and sedimentation in the upper crust as suggested by [2], and [16].

A large NNW trending gravity and magnetic low (labeled number 1; Figures 4 and 5) within the Peninsular Ranges appears to be related to density contrast in the lower crust, and upper mantle, indicating the compensation is through lateral variation in crustal and/or mantle density rather than through an Airy root [40].

We modeled a magmatic body (mixture of lower crust and upper mantle material with an assigned density of $3100 \mathrm{~kg} / \mathrm{m}^{3}$ ) model (B-B') that underlies to the southwest of the Salton Sea at a depth of about $18 \mathrm{~km}$, and extends in SW-NE direction for $90 \mathrm{~km}$ and extend vertically for about $6 \mathrm{~km}$. We expect this magmatic body plays a significant role in the process of heating the crust, stretching and rifting. No evidence for such body to the north, reference [41] modeled a similar magmatic body under lower Gila River at depth of 27 km.

\section{Conclusions}

Incorporation of receiver functions, gravity, and aeromagnetic data enable us to study a broad area of the Salton Trough to determine its deep structure and answer important questions regarding the evolution of the Salton Trough crust. Receiver function analysis suggests the Moho is $20 \mathrm{~km}$ deep to the southwest of the Salton Sea and deepens to $32 \mathrm{~km}$ in the region east of the Salton Trough. Our models and data suggest that the lower crust of the Salton Trough is oceanic (gabbroic) in composition, not a mixture of oceanic and continental crust. The low gravity and low magnetic anomalies observed along the costal margin of the Salton Trough are an indication for the absence of Airy root beneath Peninsular Ranges. Magmatic body exists to the southwest of Salton Sea at depth of about $18 \mathrm{~km}$, and extends for about $90 \mathrm{~km}$ in SW-NE direction, such body plays a significant role in heating, stretching and rifting of the crust.

\section{Acknowledgements}

We would like to thank Dr. Diane Doser, Dr. Terry Pavlis, Dr. William Cornell and Dr. Vladik Kreinovich, Dr. Jon Spencer for helpful discussions. We would like also to thank Dr. Raed Al-Douri, Carlos Montana for the technical support. The work was partially supported by NSF grant number HRD-0734825.

\section{References}

[1] S. Larsen and R. Reilinger, “Age Constraints for the PreSent Fault Configuration in the Imperial Valley, California: Evidence for Northwestward Propagation of the Gulf of California Rift System,” Journal of Geophysical Research, Vol. 96, No. 5624, 1991, pp. 10339-10446. doi:10.1029/91JB00618

[2] G. Fuis, W. Mooney, J. Healey, G. McMechan and W. Lutter, "A Seismic Refraction Survey of the Imperial Valley Region, California,” Journal of Geophysical Research, Vol. 89, No. 2, 1984, pp. 1165-1189. doi:10.1029/JB089iB02p01165

[3] V. Bankey, A. Cuevas, D. Daniels, C. Finn, I. Hernandez, P. Hill, R. Kucks,W. Miles, M. Pilkington, C. Roberts, W. Roest, V. Rystrom, S. Shearer, S. nyder, R. Sweeney, J. Velez, J. Phillips and D. Ravat, "Digital Data Grids for the Magnetic Anomaly187 Map of North America,” US Geological Survey Open-File Report, Denver, 2002.

[4] R. Larson, H. Menard and S. Smith, "Gulf of California: A Result of Ocean Floor Spreading and Transform Faulting,” Science, Vol. 161, No. 3843, 1968, pp. 781-784. doi:10.1126/science.161.3843.781

[5] D. Moore and E. Buffington, "Transform Faulting and Growth of Gulf of California Since the Late Pliocene," Science, Vol. 161, No. 3847, 1968, pp. 1238-1241. doi:10.1126/science.161.3847.1238

[6] W. Elders, R. Rex, T. Mediva, P. Robimson and S. Biehler, "Crustal Spreading in Southern California," Science, Vol. 178, No. 4056, 1972, pp. 15-24. doi:10.1126/science.178.4056.15

[7] J. Crowell, "Sedimentation and Tectonics along the San Andreas Transform Belt,” In: A. G. Sylvester and J. C. Crowell, Eds., Field Trips for the 28th International Geological Congress Sedimentation and Tectonics of North America Belt, American Geophysical Union, Washington DC, 1989, pp. 32-35.

[8] P. Lonsdale, "Geological and Tectonic History of the Gulf of California,” In D. Wintere, M. Husson and R. Decker, Eds., The Eastern Pacific Ocean and Hawaii, Geological Society of America, New York, 1989, pp. 499-521.

[9] J. Stock, and K. Hodges, "Transfer of Baja California to the Pacific Plate,” Tectonics, Vol. 8, No. 1, 1989, pp. 99115. doi:10.1029/TC008i001p00099

[10] G. Axen, M. Grove, D. Stockli, O. Lovera, D. Rothstein, J. Fletcher, K. Farley and P. Abbott, “Thermal Evolution of Monte Blanco Dome: Low Angle Normal Faulting during Gulf of California Rifting and Eocene Denudation of the Eastern Peninsular Ranges,” Tectonics, Vol. 19, No. 2, 2000. pp. 197-212. doi:10.1029/1999TC001123

[11] D. Karig and W. Jensky, "The Protogulf of California," Earth and Planetary Science Letters, Vol. 17, No. 1, 1972, pp. 169-174. doi:10.1016/0012-821X(72)90272-5

[12] D. Moore, "Plate Edge Deformation and Crustal Growth, 
Gulf of California Structural Province,” Geological Society of America Bulletin, Vol. 84, No. 6, 1973, pp. 883-1906. doi:10.1130/0016-7606(1973)84<1883:PDACGG>2.0.C $\underline{\mathrm{O} ; 2}$

[13] J. Curry and D. Moore, "Geological History of the Mouth of the Gulf of California,” In: J. K. Crouch and S. B. Bachmna, Eds., Tectonics and Sedimentary along the California Margin, Pacific Section, Society of Economic Paleontologists and Mineralogists, Bakersfield, 1984, pp. 17-36.

[14] R. Gastile, "Proceeding of Conference of Geologic Problems of the San Andreas Fault System," Stanford University Publication Geological Sciences, Vol. 11, 1968, pp. 283-286.

[15] R. Dokka and R. Merriam, "Late Cenozoic Extension of Northeastern Baja California," Geological Society of America Bulletin, Vol. 93, No. 5, 1982, pp. 371-378. doi:10.1130/0016-7606(1982)93<371:LCEONB>2.0.CO; 2

[16] T. Parsons, J. McCarthy and G. Thompson, "Very Different Crustal Response to Extreme Extension in the Southern Basin and Range and Colorado Plateau Transition,” In: M. C. Erskine, J. E. Faulds, J. M. Bartley and P. D. Rowley, Eds., American Association of Petroleum Geologists Pacific Section Guidebook, Vol. 78, 2001, pp. 291304.

[17] A. Gonzalez-Fernandez, J. Danobeitia, L. Delgado-Argote, F. Michaud, D. Ccrdoba and R. Bartolome, "Mode of Extension and Rifting History of Upper Tiburón and Upper Delfín Basins, Northern Gulf of California,” Journal of Geophysical Research, Vol. 110, 2005, B01313.

[18] D. Lizarralde, G. Axen, H. Brown, J. Fletcher, A. Gonzalez-Fernandez, A. Harding, W. Holbrook, G. Kent, P. Paramo, F. Sutherland and P. Umhoefer, "Variation in Styles of Rifting in the Gulf of California," Nature, Vol. 448, 2007, pp. 466-469. doi:10.1038/nature06035

[19] R. Bialas and W. Buck, "How Sediment Promotes Narrow Rifting: Application to the Gulf of California," Tectonics, Vol. 28, 2009, TC4014. doi:10.1029/2008TC002394

[20] R. Dorsey, "Sedimentation and Crustal Recycling along an Active Oblique-Rift Margin: Salton Trough and Northern Gulf of California," Geological Society of America, Vol. 38, 2010, pp. 443-446.

[21] C. Ammon, G. Randall and G. Zandt, "On the Nonuniqueness of Receiver Function Inversions,” Journal of Geophysical Research, Vol. 95, 1990, pp.15303-15318.

[22] L. Zhu and H. Kanamori, "Moho Depth Variation in Southern California from Teleseimic Receiver Function,” Journal of Geophysical Research, Vol. 105, No. B2, 2000, pp. 2969-2980. doi:10.1029/1999JB900322

[23] J. Ligorria and G. Ammon, "Iterative Deconvolution and Receiver Functions Estimation," Bulletin of Seismological Society of America, Vol. 89, 1999, pp. 1395-1400.

[24] L. Zhu, "Estimation of Crustal Thickness and Vp/Vs Ratio beneath the Tibetan Plateau from Teleseismic
Converted Waves (Abstract)," Eos Transactions American Geophysical Union, Vol. 74, No. 16, 1993, p. 202.

[25] G. Zandt, S. Myers and T. Wallace, "Crust and Mantle Structure across the Basin and Range Colorado Plateau Boundary at $37^{\circ} \mathrm{N}$ Latitude and Implication for Cenozoic Extensional Mechanism," Journal of Geophysical Research, Vol. 100, No. B6, 1995, pp. 10529-10548. doi:10.1029/94JB03063

[26] G. Zandt and C. Ammon, "Continental Crust Composition Constrained by Measurements of Crustal Poisson Ratio,” Nature, Vol. 374, No. 6518, 1995, pp. 152-154. doi:10.1038/374152a0

[27] D. Eaton, S. Dineva and R. Mereu, "Crustal Thickness and $V_{p} / V_{s}$ Variations in the Grenville Orogen (Ontario, Canada) from Analysis of Teleismic Receiver Function," Tectonophysics, Vol. 420, No. 1-2, 2006, pp. 223-238. doi:10.1016/j.tecto.2006.01.023

[28] T. Nakajima, T. Matsuzawa, A. Hasegawa and D. Zaho, "Three Dimensional Structure of $V_{p}, V_{s}$, and $V_{p} / V_{s}$ beneath Northeastern Japan: Implications for Arc Magmatism and Fluids," Journal of Geophysical Research, Vol. 106, No. B10, 2001, pp. 21843-21857. doi:10.1029/2000JB000008

[29] M. Webring, "MINC, a Gridding Program Based on Minimum Curvature,” US Geological Survey Open-File Report 81-1224, 1982, p. 43.

[30] D. Plouff, "Preliminary Documentation for a Fortran Program to Compute Gravity Terrain Corrections Based on Topography Digitized on a Geographic Grid,” US Geological Survey Open File Report 77-535, 1977, p. 45.

[31] B. Baranov and H. Naudy, "Numerical Calculation of the Formula of Reduction to the Magnetic Pole," Geophysics, Vol. 29, No. 1, 1964. pp. 67-79. doi:10.1190/1.1439334

[32] R. Blakely, "Potential Theory in Gravity and Magnetic Applications,” Cambridge University Press, New York, 1995. doi:10.1017/CBO9780511549816

[33] M. Talwani, J. Worzel and M. Landisman, "Rapid Gravity Computations for Two-Dimensional Bodies with Application to the Mendocino Submarine Fracture Zone," Journal of Geophysical Research, Vol. 64, No. 1, 1959, pp. 49-59. doi:10.1029/JZ064i001p00049

[34] L. Pedersen, "Interpretation of Potential Field Data, a Generalized Inverse Approach,” Geophysical Prospecting, Vol. 25, No. 2, 1977. pp. 199-230. doi:10.1111/j.1365-2478.1977.tb01164.x

[35] J. Cady, "Calculation of Gravity and Magnetic Anomalies of Finite-Length Right Polygonal Prisms,” Geophysics, Vol. 45, No. 10, 1980, pp. 1507-1512. doi:10.1190/1.1441045

[36] C. Jennings, "Geologic Map of California. Scale 1: 750,000, California,” Department of Mines and Geology, 1997.

[37] S. Reynolds, "Geological Map of Arizona. Scale 1: 1,000,000,” Arizona Geological Survey, 1988.

[38] T. Parsons and T. McCarthy, "Crustal and Upper Mantle Velocity Structure of the Salton Trough Southeast Cali- 
fornia,” Tectonics, Vol. 15, No. 2, 1996, pp. 456-471. doi:10.1029/95TC02616

[39] V. Langenheim, R. Jachen, J. Matti, E. Hauksson, D. Morton and A. Christensen, "Geophysical Evidence for Wedging in the San Gergonio Pass Structural Knot, Southern San Andreas Fault Zone, Southern California,” GSA Bulletin, Vol. 117, No. 110, 2005. pp. 1554-1572. doi:10.1130/B25760.1

[40] J. Lewis, S. Day, H. Magistrale, J. Ealins and F. Vernon, "Regional Crustal Variations off the Peninsular Ranges, Southern California,” Geology, Vol. 28, No. 4, 2000, pp. 303-306.

\section{Websites}

NSF, “Earthscope,” 2006. http//www. earthscope.org/ NSF, "Earthscope Automated Receivers Survey (EARS)," 2006. http://www.ears.iris.washington.edu UTEP, "Pan-American Center for Earth and Environmental Studies,” 2006. http://research.utep.edu/paces
doi:10.1130/0091-7613(2000)28<303:RCTVOT>2.0.CO; $\underline{2}$

[41] M. Hussein, "Integrated and Comparative Geophysical Studies of Crustal Structure of Pull-Apart Basins: The Salton Trough and Death Valley, California Regions," Ph.D. Dissertation, University of Texas at El Paso, El Paso, 2007.

[42] R. Dorsey, "Stratigraphic Record of Pleistocene Initiation and Slip on the Coyote Creek Fault, Lower Southern California,” In: A. Bath, Ed., Contributions to Crustal evolution of the southwest United States, Geological Society of America, 2002, pp. 251-269. 